(C) 2019 International Journal of Nursing and Health Services

This is an Open Access article distributed under the terms of the Creative Commons Attribution 4.0 International License which permits unrestricted non-commercial use, distribution, and reproduction in any medium, provided the original work is properly cited

\title{
LEVEL OF KNOWLEDGE REGARDING PAP SMEAR EXAMINATION AMONG THE CHILDBEARING AGE WOMEN'S IN RW O4 RT 05, RANGKAPAN JAYA BARU, PANCORAN MAS DEPOK
}

\section{Hendrawati ${ }^{1}$}

\author{
1 Politeknik Karya Husada Jakarta, Indonesia \\ * Correspondence: hendrawatikamil@gmail.com
}

\begin{abstract}
Level of knowledge of women in childbearing age regarding pap smear consider low. A analytic descriptive study design was used to describe the level of knowledge regarding pap smear examination among the childbearing age women. Data collection tools were questionnaire in form of checklist. The results confirmed that 39 from 75 participants have an excellent level of knowledge,
\end{abstract}

Keywords: knowledge, childbearing age women's, Pap smear

\section{Introduction}

Cervical cancer is a lethal disease for women's. In the world, mortality rate due to it is estimated will increase by $25 \%$ over the next 10 years. More than 270.000 mortality rate in the developing countries compared with the developed countries (1). WHO stated that risk of cervical cancer in developing cancer is improving as a result of unhealthy life style and community attitude especially in term of early free sex before married (1). Based on data by the basic health research in 2013, cancer prevalence in Indonesia is 4.1 per 100.000 people or around 330.000 persons (2).

The highest cancer disease in Indonesia among women's is breast and cervical cancer. Cervical cancer or neck uteri cancer is a malignant process that occurs in the cervical, it is the lowest part of uterus that protrudes into the intercourse or vagina. This process caused the surrounding tissues could not do 
their functions properly (3). Furthermore, the accompanied symptoms are bleeding and abnormal discharge of vaginal fluid (3). Cervical cancer, is a cancer that occurs in the uterine cervix where the area of the female reproductive organ. It is located between uterus and vagina. Time needed for cervical cancer to develop is around 10-15 years. Cancer commonly happens in women's aged between 30 - 50 years old, which is reproductive age for women's (4).

Several factors that are considered increase the incidence of cervical cancers are age, socio- economic factors, knowledge and education. In the elderly, risk of cervical cancer increased, as an accumulation of increasing duration to exposure to the carcinogens agent and the reducing of immune status because of aging process (5).

Knowledge and education level of mother's regarding cervical cancer would form the positive attitude regarding the low number early detection of it. This is the dominant factor in an early detection examination of cervical cancer. Level of knowledge and education have by the women's in childbearing age will lead to the belief of mothers regarding the early detection of cervical cancers. In the preliminary surveys, from 75 women's of child bearing ages in RW 04 RT 05, Rangkap Jaya Baru subdistric, Pancoran Mas, Depok it was found that 6 only people had knowledge regarding pap smear. Based on it, it is important to established research to assess level of knowledge of the childbearing age women's regarding Pap smear examination.

A pap smear is an examination method for examining the cervical wall fluid cells using microscope. It is conducted quickly, without pain and gives an accurate result (6). It is an easy, safe way to detect cervical cancer through the examination of mucus in the vagina wall (6). Besides that, it is stated that Pap smear is one of the early detection of cervical cancer, which the principle is by taken the epithelial cells in the cervix to see the normality. Cervical cancer could happen to everyone. Start from low economic level up to the high economic level, then, from those with basic education to highly educated, from teenage through the elderly. Pap smear is a screening method to check the abnormality for the women who does not have any complains related to the early stage of cancer (6).

The purpose of Pap smear examination is to detect the growth of cells that will become cancer. It also exams the normality of cells in the cervix, detects pre cancer stage in the cervix and also infectious caused by the urogenital and others disease transmitted by sexual intercourse. This test also examined and detected the abnormal cell, which is contained only in the outer layer of the cervix, and not invading the inside. It also, could reflect the level of malignancy of cervical cancer.

Several factors could affect the pap smear examination including the social and demographical factors. Those factors could influence a person in seeking treatment and using health services. According to other study stated that there was a relationship between age and the selection of health service. Commonly. Through the age period, a person will improve their comprehension regarding health services regarding their mindset. Educational factors are factors that influence people's behavior in health, which in turn will have an impact on health status. For the knowledge factors refer to the result of not know to know it. It could happen because someone does sensing certain objects. Ignorance or the inadequate level of

International Journal of Nursing and Health Services (IJNHS), Volume 2, Issue 2, 2019 | 83 
knowledge regarding prevention of cervical cancer through pap smear will lead to the low number of early detection. Furthermore, if a woman has adequate knowledge, it could create a belief and motivation in conducting the early detection of cervical cancer (7).

\section{Objectives}

The study aimed to describe the level of knowledge regarding pap smear examination among the childbearing age women.

\section{Methods}

The study used analytic descriptive method. It was obtained from the sample by listing it in the questionnaire form. Analytical research approach used to analyze the knowledge, education, economy, attitude to the pap smear examination.

The population and sample in this research were all childbearing age women's in RT 05 RW 04, Rangkapan Jaya Baru, Pancoran Mas, Depok with total number of 75 people. Sampling technique used in this study was accidental sampling which sample was taken based on the availability of the sample $(8,9)$.

\section{Results}

Table 1. Frequency distribution of respondent characteristic

\begin{tabular}{|lcc|}
\hline Characteristics & Frequency (n) & Percentage (\%) \\
\hline Age & 29 & 38.7 \\
20 - 40 years old & 39 & 52.0 \\
41 - 60 years old & 7 & 9.3 \\
61 - 80 t years old & & \\
Educational & 22 & 29.3 \\
$\quad$ Senior High School & 15 & 20 \\
Diploma degree & 38 & 50.6 \\
Bachelor degree & & \\
Income & 48 & 64 \\
No income & 5 & 6.7 \\
Rp. 1.000 .000 - Rp. 3.999 .990 & 9 & 12 \\
Rp.4.000.000 - Rp. 5.999.990 & 13 & \\
Rp. 6.000.0000 - Rp. 40.000 .000 & & \\
\end{tabular}

Based on table, it shows the percentage of respondent characteristics based on age, educational and income. It can be seen the majority of respondent aged was 41-60 years old (52\%), holding bachelor degree (50.6\%) and not had income (64\%).

Table 2. Level of knowledge of participant's

\begin{tabular}{lcc}
\hline Criteria & Frequency $(\mathrm{n})$ & Percentage (\%) \\
\hline Lack of knowledge regarding pap smear & 5 & 6.7 \\
Moderate knowledge regarding pap smear & 31 & 41.3 \\
Excellent knowledge regarding pap smear & 39 & 52.0 \\
\hline Total & 75 & 100 \\
\hline
\end{tabular}


In table 2, it can be seen that from 75 person of childbearing age women's in RT 05 RW 04 Pancoran Mas Depok, there were 5 persons (6.7\%) with lack of knowledge, 31 persons (41.3\%) with moderate knowledge and 39 person (52\%) with excellent knowledge. According to the theory stated by Notoatmodjo stated that knowledge is the result of knowing from humans, this becomes after people have sensed a particular object. Learning occurs through the five human senses, namely the senses of vision, hearing, smell, taste and touch. Most human knowledge is obtained through the eyes and ears (10). Based on that, it can be concluded that the knowledge possessed by humans can overcome health problems that arise in the future. Ignorance and lacking knowledge of childbearing age women's on the prevention of cervical cancer through pap smears could lead to early detection of cervical cancer. Besides that, if a woman has extensive knowledge it will lead to high confidence in the early detection of cervical cancer.

Table 3. Frequency distribution of Pap smear examination

\begin{tabular}{lcc}
\hline Criteria & Frequency $(\mathrm{n})$ & Percentage (\%) \\
\hline Never do pap smear & 39 & 52.0 \\
Already do pap smear & 36 & 48.0 \\
\hline Total & 75 & 100 \\
\hline
\end{tabular}

In table 3 , it can be reflected that there were 39 person (52\%) never did pap smear whereas 36 person (48\%) already did it. This data obtained from interview and also questionnaire filled by the participants. The frequency of Pap smear was two times within 3-4 years interval.

Table 4. Frequency distribution regarding reason refusing pap smear

\begin{tabular}{lcc}
\hline Criteria & Frequency $(\mathrm{n})$ & Percentage $(\%)$ \\
\hline Expensive & 13 & 33.3 \\
Fear & 20 & 51.3 \\
Shy & 6 & 15.4 \\
\hline Total & 39 & 100 \\
\hline
\end{tabular}

Majority of participant refusing pap smear due to fear, which was 20 person (51.3\%), other refuses due to expensive which was 13 person (33.3\%) and 6 person (15.4\%) refuses because of shy. So it can be concluded that, dominantly, childbearing age women's feels insecure with the procedure so that they forget about their own health.

\section{Discussion}

Education is a formal process, which is carried out continuously from higher adjustment for an individual that have developed physically, mentally, intellectual, emotionally and humanity. In this study, majority of participant holding bachelor degree $(37.3 \%)$ while in contrast for junior high school student only six person $(8 \%)$.

International Journal of Nursing and Health Services (IJNHS), Volume 2, Issue 2, 2019 | 85 
Knowledge of childbearing age women's is an important aspect especially knowledge regarding pap smears. Without insufficient knowledge, patients will feel doubtful and did not consider it as important things like in table 4. Dominantly, 39 persons of sample (52\%) had excellent knowledge of pap smear. Whereas 39 participants (53\%) fear with the pap smear examination. This finding was similar by study of Balogun el al (2012) that found age and education were positively correlated with the willingness to undergo the screening $(p<0.05)(11)$.

Notoatmodjo stated that knowledge is a process of knowing after sensing a particular objects. Sensing of it could be established through five senses of human beings, which are seeing, hearing, smelling, testing and touching (12). Based on it theory, it can be concluded that the knowledge possessed by humans could overcome health problems in the future. One of it, is cervical cancer, which is an early detection is needed. Lack or low level of knowledge of childbearing women's age regarding prevention of cervical cancer through the pap smear lead to the low number of early detection of it. In parallel with it, a woman with an excellent knowledge of pap smear examination will lead to belief and full confidence in doing the early prevention of cervical cancer (12).

\section{Relationship between level of knowledge with the pap smear examination in the child bearing women's age}

Knowledge is the result of information that has been processed and organized to gain understanding, learning and accumulating experience so that it could be applied to certain problems. Furthermore, information processing to extract critical implications and reflecting it on past experiences that provides recipients with high knowledge organizational valued. Knowledge could also be referred as symptoms encounters and obtains by humans through observation. When an individual uses his minds to recognize a certain events that have never been felt before, it could bring up knowledge. Basically, knowledge has predictive ability to recognize certain things as results of the introduction of a pattern. Information could make an individual confuse, due to it knowledge leads action of a person. Majority human knowledge is obtained through the eyes and ears. Knowledge is a significant domain in establishing an individual attitude. Moreover, behavior based on knowledge will last longer that not on it (13).

In this research, it was found that almost half sample which was $48 \%$ already did the Pap smear. It is quite similar with other study in Malaysia that found the prevalence of women did the Pap smear test was 58.1 (14). Furthermore, other study found that $65.1 \%$ of the respondent did the Pap smear test (15). Contrary, the study in Haitian women that found only one in three women had been screen for cervical cancer (16). Besides that another study found that only 5\% respondent underwent the Pap smear test (17).

Based on the results of univariate analysis, it was showed that the majority of respondents in RT 05 RW 04 Pancoran Mas Depok, had an excellent knowledge regarding pap smear which was 39 (52\%) childbearing age women's. There are some respondents was lack of knowledge based on the table 2. Childbearing women's age that never did Pap smear examination was 39 (52\%) person with the

International Journal of Nursing and Health Services (IJNHS), Volume 2, Issue 2, 2019 | 86 
reason of fear was $51.3 \%$. Besides that, in the childbearing age women's there were still not exposed yet with the Pap smear examination both in terms of their understanding and benefits. Moreover, counseling about Pap smear it is needed for women's. Chi-square test result shown that the level of knowledge variable had a significant relationship with the Pap smear examination with the significance pvalue $=0.013<\alpha=0.05$. So it can be concluded that there was significance relationship between levels of knowledge of childbearing women's with the Pap smear examination in RT 05/ RW. 04 Kelurahan Rangkapan Jaya Baru Kecamatan Pancoran Mas Depok district at 2017.

This result of study is quite different with the study of Martini (2013) at Sukawati II community health center, Denpasar. In that research, it was found that the knowledge variable was not significantly related to the pap smear examination with the P value 0.999 ( $p>0.05$ ) (18). Furthermore, another study found that pap test performance was significantly higher in those who had higher knowledge $(\mathrm{P}<$ $0.001)(19)$.

This study result also incoherence with the results of the study conducted by Situmorang (2015) at RSUP Dr. Kariadi Semarang stated that there was no significance relationship between knowledge to the behavior of pap smear examination with the early detection of cervical cancer ( $p$ value $=0,054$ ) (20). Moreover, other study established that poor knowledge score was associated with poor attitude $(95 \% \mathrm{CI}, \mathrm{P}<0.001)(21)$.

In addition, there were also other studies stated no strong relationship between level of knowledge with the early detection of cervical cancer through pap smear examination. Moreover, Puspitasari (2011) stated that there was no relationship between level of knowledge with the pap smear examination (22).

However, there were some researchers similar with this study. In Widyasari (2010) at Mander Tambakboyo Tuban stated that there was a relationship between level of knowledge and motivation of childbearing age women's in carried out the pap smear examination with $P=0,000>p=0,05$ means that Ho was rejected (23).

According to the research of Oktavyani (2015) at Semanu Gunung Kidul community health center, shown that the knowledge variable had significance relationship with the pap smear examination with $p$ value $=0,003(p<0,05)(22)$.

This research is also in line with the study establish by Kusumawardani (2012) at Semarang Health District that found the statistical test with a 5\% significance level obtained $p$ value with $0,005(p<0,05)$. It means that Ho rejected so the Ha accepted so there was a relationship between knowledge of pap smear with the pap smear examination (22).

The differences from the various studies could might caused by the differences in the community conditions especially for the childbearing age women's, such as the numerous information flow, the life pattern of the community, geographical conditions and the differences in the community characteristics. The low level of knowledge regarding pap smear in Indonesia, dominantly cause by lacking of public awareness regarding cervical cancer. As well as information regarding the prevention and early detection of pap smears.

Increased knowledge dose not always cause changes in the behavior of childbearing age women's. But, it will show a positive relationship between those

International Journal of Nursing and Health Services (IJNHS), Volume 2, Issue 2, 2019 | 87 
variables. Due to it, if the knowledge of childbearing women's age improve, consequently, their attitude to it would be good also.

Knowledge possessed by the childbearing age women's on pap smear examination as the early detection of cervical cancer, indirectly affects women of childbearing age to do cancer prevention for the pap smear examination. Because of, with the existing knowledge of the childbearing age women's, they will aware and anticipate the occurrence of cervical cancer and vice versa of it. Furthermore, if childbearing age women's have extensive knowledge it will lead to the confidence to do the early detection of cervical cancer. Besides that, knowledge is the result of knowing of human beings.

\section{Conclusion}

Based on the research results, it can be concluded that pap smear examination is a cytological examination of the cervix and portion to see changes or malignancies in the cervical epithelium or portion as an initial sign of cervical or precancerous malignancy (22). Pap smear examination is a method of examining cells taken from the cervix an then examined under the microscope. Based on chi square test regarding knowledge, it was shown that there was significance relationship between pap smear and level of knowledge of participant's with a significant $\mathrm{p}$-value $=0.019<\alpha=0.05$. So, in a nutshell, there was a relationship between knowledge of childbearing age women's and the pap smear examination.

\section{References}

1. Andrijono, dkk, Cegah dan deteksi kanker serviks, Jakarta; PT Elex Media Komputindo.2010.

2. Kusumawardani NE, Faktor-faktor yang berhubungan dengan praktik pemeriksaan pap smear pada wanita bekerja, Artikel Ilmiah, Fakultas Kesehatan Masyarakat Universitas Dian Nuswantoro Semarang. 2013.

3. Depkes RI, Pedoman Penemuan dan Penatalaksanaan Penyakit Kanker Tertentu di Komunitas. Jakarta. 2007.

4. Anggraini NN, et all. Hubungan pengetahuan dan sikap wanita PUS dengan deteksi dini CA Cerviks melalui pap smear di desa ketanen kabupaten Pati, 2015.

5. Darnindro, Nikko dkk, Pengetahuan sikap perilaku perempuan yang sudah menikah mengenai pap smear dan factor yang berhubungan di RS. Klender Jakarta, FKUI. 2006,

6. Yuyun, Asuhan kebidanan khususnya pada gangguan system reproduksi dengan karsinoma serviks uteri dengan pendekatan manajemen varney, Semarang, Karya Tulis Ilmiah. 2010.

7. Suprihatiningsih, Hubungan tingkat pengetahuan dan sikap dengan pemeriksaan pap smear pada ibu di Desa Rowosari Kabupaten Kendal, 2015

8. Nursalam, Konsep dan penerapan metodologi penelitian ilmu keperawatan. Edisi 2 Jakarta : Salemba Medika. 2011.

9. Notoadmojo, S. Metodologi Penelitian Kesehatan. Jakarta: PT. Rineka Cipta ; 2010. 
10. Notoatmodjo S, Pengantar Pendidikan Kesehatan dan Ilmu Perilaku Kesehatan, Rineke Cipta Jakarta. 2003,

11. Balogun MR, Odukoyo 00, Oyediran MA, Ujomu PI. Cervical cancer awareness and preventive practices: a challenge for female urban slum dwellers in Lagos, Nigeria. African Journal of Reproductive Health. 16 (1) : 75.2012.

12. Indrawati, Pengaruh Pendidikan Kesehatan Tentang Kanker Serviks Terhadap Perubahan ,2009.

13. Notoadmojo, Promosi Kesehatan dan Perilaku. Jakarta, Rineka Cipta. 2011.

14. Abdullah, NN, Al-Kubaisy W, Moktar MM. Health behavior regarding cervical cancer in screening among urban women in Malaysia. Procedia Social and Behavioral Science. 85 : 110-117. 2013. Available at: https://www.sciencedirect.com/science/article/pii/S1877042813024701

15. Assoumou SZ, Mabika BM, Mbiguino AN, Mouallif M, Khattabi A, Ennaji MM. Awarenees and Knowledge regarding cervical cancer, pap smear screening and human papillomavirus infection in Gabonese women. BMC Womens Health. 15 : $37.2015 . \quad$ Available at bahttps://bmcwomenshealth.biomedcentral.com/articles/10.1186/s12905015-0193-2

16. Mc Carthy SH, Walmer KA, Boggan JC, Gichane MW, Calo WA, Beauvais HA MD. Awareness of Cervical Cancer causes and pre determinants of likelihood to screen among Women in Haiti. Journal Lower Genital Tract Dis. 21 (1) : 37-41. 2018

17. Shah V, Vyas S, Singh A, Shrivastava M. Awarenees and knowledge of cervical cancer and its prevention among the nursing staff of a tertiary health institute in Amedabad, Gujarat, India. 6: 270. 2012. E cancer medical science

18. Niketut Martini, Hubungan karakteristik, pengetahuan dan sikap wanita pasangan usia subur dengan tindakan pemeriksaan pap smear di Puskesmas Sukawati II, 2013

19. Ashtarian H, Mirzabeigi E, Mahmoodi E, Khezeli M. Knowledge about Cervical Cancer and Pap Smear and the factor influencing the pap test screening among women. International Journal of Community Based Nursing - Midwify. 5 (2) : 188-195. 2017

20. Situmorang MJ, et all, Hubungan pengetahuan dan sikap dengan perilaku deteksi dini pada penderita kanker serviks di RSUP DR.Kariadi Semarang, 2015, Jurnal Kesehatan Masyarakat Vol 4 No 1, ISSN 2356-3346, 2016.

21. Aweke YH, Ayanto SY, Ersado TL. Knowledge, attitude and practice for cervical cancer prevention and control among women of childbearing age in Hossana Town, Hadiya zone, Southern Ethiopia : Community-based cross-sectional study. PLoS One 12(7). 2017. e0181415. Available at https://doi.org/10.1371/journal.pone.0181415

22. Oktavyany $S$, et all. Hubungan tingkat pengetahuan tentang kanker serviks dengan sikap terhadap pemeriksaan pap smear pada PUS di Puskesmas Semanu Gunung Kidul, Jurnal Permata Indonesia, Vol 6 No 2 ISSN 2086-9185, 2015

23. Widyasari Y. Hubungan antara pengetahuan dan motivasi wanita PUS dalam melakukan pemeriksaan pap smear. 